\title{
Construction Project Quality Management using Building Information Modeling 360 Field
}

\author{
Phong Thanh Nguyen ${ }^{1 *}$, Khoa Dang Vo ${ }^{4}$, Phuong \\ Thanh Phan ${ }^{7}$ \\ Department of Project Management \\ Ho Chi Minh City Open University (HCMCOU) \\ Ho Chi Minh City, Vietnam
}

\author{
Thu Anh Nguyen ${ }^{2}$, Tin Minh $\mathrm{Cao}^{3}$ \\ Department of Construction Engineering and Management \\ Ho Chi Minh University of Technology (HCMUT) \\ Ho Chi Minh City, Vietnam
}

\author{
Vy Dang Bich Huynh ${ }^{5}$ \\ Department of Learning Material \\ Ho Chi Minh City Open University (HCMCOU) \\ Ho Chi Minh City, Vietnam
}

\author{
Quyen Le Hoang Thuy To Nguyen ${ }^{6}$ \\ Office of Cooperation and Research Management \\ Ho Chi Minh City Open University (HCMCOU) \\ Ho Chi Minh City, Vietnam
}

\author{
Loan Phuc Le ${ }^{8}$ \\ School of Advanced Study \\ Ho Chi Minh City Open University (HCMCOU) \\ Ho Chi Minh City, Vietnam
}

\begin{abstract}
A quality management process plays a vital role in the success of engineering and construction projects. The management process needs to be effective and efficient if projects are to be completed on time and within the project's budget. Many construction projects' quality management processes are paper-based, which makes them time-consuming and inefficient. The next generation of Building Information Modeling (BIM) is the BIM-cloud. The BIM-cloud can help to enhance the effectiveness of a quality management process; it can also save an organization time and money. This paper proposes a quality management model based on cloud computing, mobile devices, and the Autodesk BIM 360 Field software. This software functions as a platform for gathering, managing and controlling the quality of the management data. The process is then applied to a real project in Vietnam to verify the benefits and barriers of using the BIM 360 Field for a construction project.
\end{abstract}

Keywords-BIM 360 field; cloud computing; project management; quality management

\section{INTRODUCTION}

Construction projects are unique, because they serve the business production and meet human's basic demands [1-3]. As a result, the quality of a construction and engineering project directly influences the stable development and effectiveness of the socioeconomic factors of the national economy [4-7]. Additionally, in a fiercely competitive market economy, an improvement in the management quality has always been considered a crucial leading issue for construction companies [8]. To ensure a high quality project, a quality management process must be performed during all stages of a project (e.g., survey, design, the organization of the construction process, the maintenance of the project) $[9,10]$. The construction process is the most complicated process. This is because the quality control process, at this stage, is also complicated; therefore, it is easy to make mistakes [11]. Good project quality management helps contractors save money on materials, workers, and equipment. It would also enhance the contractor's reputation in the market.

To ensure a high-quality management process, the collection and processing of information and the interaction between project stakeholders must be constant and accurate. Hence, the project management process involves an enormous amount of information. Consequently, the development of a system that could access and grasp project information quickly, effectively, and accurately is extremely urgent and necessary.

The Autodesk Building Information Modeling (BIM) 360 Field is the next generation BIM. It combines iPads, mobile devices, cloud computing, and the BIM model [12-15]. This research applied the Autodesk BIM 360 Field to enhance the efficiency of the management quality for construction projects in Vietnam. This is a new approach used to support quality assurance activities to improve the productivity so the construction projects are effectively managed.

\section{LITERATURE REVIEW}

A high quality construction project meets all of the stipulated demands of a project (e.g., technical requirements, time, expenditures, stability degrees, safety, environment) [16]. The process of producing a high quality product begins when the construction idea is developed and continues throughout all construction processes (e.g., planning, project creation, surveys, design, construction, acceptance, delivery) $[17,18]$. To ensure a high project quality, the quality management process must be performed during all stages of the project life cycle [19]. Amongst them, the construction 
stage is considered the most complicated, as it accounts for the largest proportion of the project's cost $(70-80 \%)$. The control process and quality management during this stage are the most difficult tasks [20, 21].

According to the Vietnamese Government's Decree No. $15 / 2013$ ND-CP, construction quality management includes the following steps: (i) choosing a contract and creating and approving a construction method; (ii) checking the initial work conditions, (iii) building, supervising and accepting the project; (iv) developing the construction documents and file storage. In traditional construction quality management approaches, the supervision, acceptance, and storage of documents are often a paper-based process. A paper-based process is a timeconsuming, cost-consuming process. It is also difficult to control the quality of [22]. Therefore, the application of information technology using the BIM 360 Field in construction organization, supervision, quality acceptance, and the creation and storage of documents on the server is exceptionally crucial.

Currently, the BIM is acknowledged and developed widely in the construction industry for all types of projects (e.g., apartments, tall buildings, hotels, industrial houses, production, infrastructure works, and transportation projects) [14, 23, 24]. The BIM is a process used to develop an information model. It involves designing, building and operating a construction project [25]. As an umbrella database covering the entire life cycle of a project, the BIM includes logical relationships regarding the space, size, quantity, material, and features of the work components. The ability to combine work division information with the information regarding the norms, unit prices, construction progress, operations, and maintenance regime is becoming more and more crucial in the construction sector to optimize the design, building and project management process [26].

The BIM 360 Field is a program developed by the BIMCloud platform [27]. It integrates a 3D smart model and mobile technologies with cloud computing technology [28]. The BIM 360 Field is applied to the execution stage of a project. It assists with the cooperation, combination, and management of work information that is occurring quickly, enhancing the effectiveness of work quality management and saving time and expenditures [29]. We could apply the BIM-Cloud to the entire life cycle of a project, from planning and project formation, to the survey, design, execution, acceptance, project handover, and work dismount [30, 31]. All data relating to the project would be uploaded to the cloud. Project participants (e.g., investors, consultancy companies, contractors) would obtain available preset access rights to easily access the necessary data.

Cox et al. [32] proposed a process using the Hand Base on a personal computer to perform the acceptance stage of the construction project. Its benefits are to reduce tasks relating to papers, to create a management report and to distribute information quickly and effectively. Chen and Kamara [22] recommended a mobile computing process to manage the information at the work site. The model includes mobile devices, wireless networks, and other mobile applications to perform the information management process in a construction project. Chuang et al. [33] built a system using server software and cloud computing techniques to develop a virtual system. This virtual system was used to observe and operate a BIM 3D model through the website without any limits regarding time or space. This system creates conditions for the communication and the distribution of information between the parties taking part in the project.

Moran [34] conducted experimental research on actual projects. Some projects used the BIM 360 Field and some did not. Moran [34] proved that the usage of the BIM 360 Field based Vela Systems helps parties taking part in the project to save time, money and expenditures. They also improve the construction quality of the work. This is due to the reduction of the amendment and remade activities. Sawhney and Maheswari [35] proposed a process where the BIM-Cloud would supervise the data during the design process. The project manager could check the data of each design engineer that was uploaded to the server. Jiao et al. [36] recommended the usage of the BIMCloud Augmented Reality, a virtual reality technology, to observe and manage data in the field of design and the work execution of projects in Shanghai and China. This model integrates the usage of a 3D website and cloud technology through BIM connections and social networking services.

Davies and Harty [37] described the deployment of "Site BIM" in a hospital project. The main contractor developed the "BIM-Enable" tools, allowing employees to use a notebook to access the information regarding the design, quality report photographs, and working progress in the field. The "Site BIM" system includes five main parts: 1) notebook, 2) combined 3D BIM models, 3) a data management system (DMS), 4) "Site dBase" application software, and 5) the office project system (including the infrastructure and relevant software).

Fernandes [38] proposed a process using the BIM 360 Field for relevant parties taking part in the construction project (e.g., contractors, investors, consultants, project managers). At the same time, the author also pointed out three groups of benefits acquired from the application of the BIM 360 Field in the project, including: (i) information (good interaction and fast update of project information), (ii) operation (notification system improvement and process streamlining), (iii) management (better management of parties taking part in the project on the basis of the cloud, and the removal of traditional paper-based tasks), and (iv) quality (reduction of project costs due to the reduction of reworked tasks and the commitment of better quality).

Zhang et al. [39] proposed a BIM-Service on the private cloud. This is the place where the parties who are taking part in the project store relevant information on their private server. This model supported project stakeholders to set, manage and transfer BIM data effectively, as well as secure the information. Tsai et al. [8] proposed an effective construction project acceptance method through the BIM model on the basis of the cloud platform. In this model, the supervisors easily take photos created from the BIM model and construction information to quickly complete the inspection tasks..

Gleason et al. [40] studied three software supporting construction projects: Bluebeam, BIM 360 Field, and Latista. 
The authors concluded that Bluebeam is suitable for small construction companies, while BIM 360 Field is the best choice for companies performing BIM in large-scale projects. Latista is an optimized choice for companies not using BIM, but that are still able to perform complicated tasks. No matter what the software is, the primary aim is to improve productivity, to increase information interactions, and to reduce remade tasks and delay in a construction project. This study also gave out a quality assurance process with the assistance of mobile devices and software.

\section{RESEARCH METHODOLOGY AND RESUltS}

In this investigation, a process is proposed by applying the BIM 360 Field in the assistance of a construction quality assurance activity. The BIM 360 Field was applied in a residential construction project in District 2 of Ho Chi Minh city in Vietnam. This project includes 02 mutual underground basements and 04 housing blocks; the scale goes from 22 to 25 floors. There were 605 apartments for living and 16 commercial apartments. This project is in the process of the structural execution of a typical floor and a combination of completed construction.

TABLE I. Project Quality Management Process

\begin{tabular}{|c|c|}
\hline Without BIM 360 Field & With BIM 360 Field \\
\hline \multicolumn{2}{|l|}{ Subcontractor } \\
\hline $\begin{array}{l}\text { 1. To perform the work according to method } \\
\text { drawings and approved shop-drawings; } \\
2 \text {. To check the quality and the } \\
\text { compatibility of the execution activities; } \\
\text { 3. To send internal acceptance requirements } \\
\text { to the main contractors to determine if they } \\
\text { are meeting quality and compatibility } \\
\text { requirements; } \\
\text { 4. To amend and to modify the } \\
\text { inappropriate faults required by the main } \\
\text { contractor. }\end{array}$ & $\begin{array}{l}\text { 1. To perform the work } \\
\text { according to method drawings } \\
\text { and approved shop-drawings; } \\
2 . \text { To amend and modify the } \\
\text { inappropriate faults required } \\
\text { by the main contractor. } \\
\text { 3. To photograph the fault } \\
\text { amendment. To synchronize } \\
\text { the BIM } 360 \text { Field System. } \\
\text { The information would be } \\
\text { automatically updated for the } \\
\text { main contractor to perform } \\
\text { the acceptance for the NCRs } \\
\text { closure. }\end{array}$ \\
\hline \multicolumn{2}{|l|}{ Main contractor } \\
\hline $\begin{array}{l}\text { 1. To perform the internal acceptance with } \\
\text { the subcontractor. If the result is passed, an } \\
\text { acceptance requirement would be sent to the } \\
\text { Consultant and the Investor; by contrast, an } \\
\text { analysis of the reasons and amendment } \\
\text { methods would be performed to require the } \\
\text { subcontractor to modify and remedy them. } \\
2 \text {. When receiving NCRs from the } \\
\text { Supervision Consultant and Investor, the } \\
\text { analysis of the reasons must be performed. } \\
\text { The solutions must be submitted to the } \\
\text { Supervision Consultant and Investor for } \\
\text { approval. } \\
3 \text {. When the remedy is approved, it would } \\
\text { be employed for the amendment and } \\
\text { modification of the subcontractor. } \\
4 \text {. To perform the internal acceptance with a } \\
\text { subcontractor, and in case it is passed, the } \\
\text { acceptance requirement for NCRs closure } \\
\text { would be performed together with the } \\
\text { Supervision Consultant and the Investor. }\end{array}$ & $\begin{array}{l}\text { 1. When receiving NCRs } \\
\text { from the Supervision } \\
\text { Consultant and the Investor, } \\
\text { the analysis of the reasons } \\
\text { must be performed. The } \\
\text { solutions must be submitted } \\
\text { to the Supervision Consultant } \\
\text { and the Investor for approval. } \\
2 \text {. When the solutions are } \\
\text { approved, the main contractor } \\
\text { would make updates on the } \\
\text { BIM } 360 \text { Field and allocate } \\
\text { the NCRs position. The } \\
\text { subcontractor shall be } \\
\text { responsible for the } \\
\text { amendment and completion } \\
\text { deadline. } \\
3 \text {. The representative of the } \\
\text { contractor would sign and } \\
\text { close the NCRs if the } \\
\text { amendment meets the } \\
\text { demands. }\end{array}$ \\
\hline
\end{tabular}

The collected data would be analyzed to determine the benefits and difficulties of applying the BIM 360 Field in the project's management quality. To assure better quality, it is necessary to control the inputs and outputs carefully. The input of quality is the acceptance of tasks. The output is the control of the inappropriateness of work in comparison with the technical drawings (e.g., no conformance reports (NCRs)). Regarding the old acceptance process, an acceptance checklist is critical. This checklist would be held at the work site to perform the acceptance process. With the BIM 360 Field, it is possible to perform the acceptance on an iPad (Table 1).

The performance process applied the BIM 360 Field and involved seven steps:

Step 1. Performing the preparation and training for the project stakeholders

Step 2. Project administration would modify the BIM user and decentralize the rights. This involves the following five steps:

- Setting the general information of the project

- Setting the types of issues and the main reasons

- Setting the checklist and the forms for acceptance on the BIM 360 Field system

- Setting the types of tasks

- Setting the types of reports

Step 3. Pointing out the problems and defects necessary to remedy the image and the faulty position. Allocating the performer and the time of the execution (Figure 1).

Step 4. The information would be automatically updated on the BIM 360 Field; the subcontractor would remedy and amend. The subcontractor would then take a picture of the amended defects and update the system.

Step 5. When there was a requirement to accept on the system, the main contractor would perform the acceptance process. If it is passed, an electronic signature would be signed, and the issue, or NCRs, would be sealed.

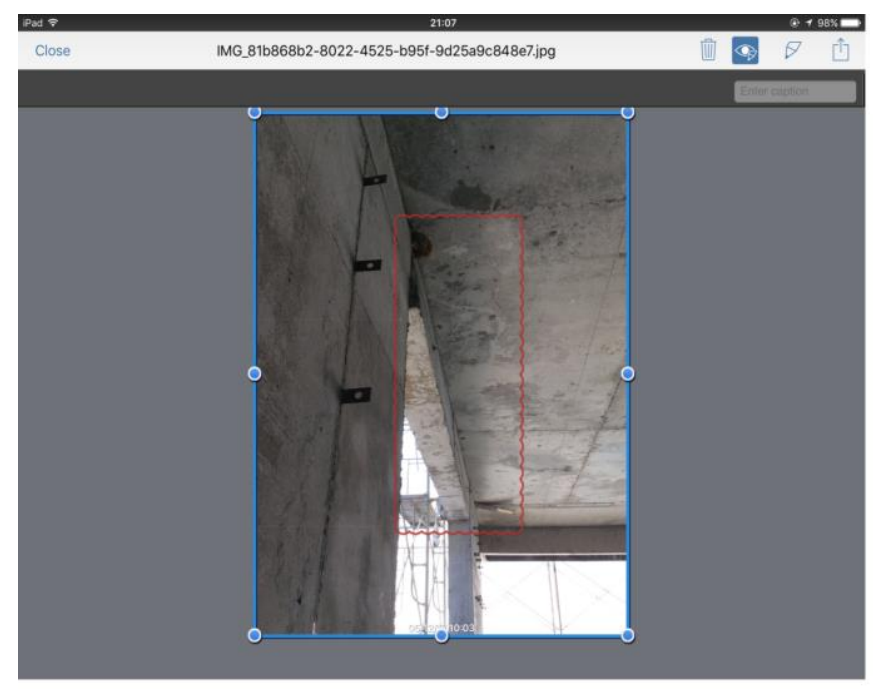

Fig. 1. Create Issues on BIM 360 Field System by iPad. 
Step 6. Publish the project quality management report presented in TABLE II, according to the causes.

The employment of the BIM 360 Field in the actual project has resulted in the following benefits to the company, as follows:

- saving 2.5 hours per day, thanks to the simplified working process; and

- saving paper, because the new procedure is mainly acceptance through iPad (Figure 2).

TABLE II. PROJECT QuALITY RoOT CAUSE

\begin{tabular}{|l|l|l|l|}
\hline No. & Cause & Issues & Percent \\
\hline 01 & $\begin{array}{l}\text { Low-quality formwork with insufficient } \\
\text { supervision and control }\end{array}$ & 22 & $5 \%$ \\
\hline 02 & $\begin{array}{l}\text { Dismounting of formwork, post, scaffold, } \\
\text { method steel, and sanitation }\end{array}$ & 25 & $5 \%$ \\
\hline 03 & $\begin{array}{l}\text { Shop drawings shall not present or } \\
\text { insufficiently }\end{array}$ & 15 & $3 \%$ \\
\hline 04 & Formwork installation is not standard & 63 & $13 \%$ \\
\hline 05 & Not using the approved method & 12 & $3 \%$ \\
\hline 06 & $\begin{array}{l}\text { Due to the differences between the drawings } \\
\text { and the structure }\end{array}$ & 66 & $14 \%$ \\
\hline 07 & $\begin{array}{l}\text { The position of the formwork to the columns } \\
\text { and the incorrect wall }\end{array}$ & 17 & $4 \%$ \\
\hline 08 & $\begin{array}{l}\text { The position of the formwork is not in } \\
\text { accordance with the geodetic level }\end{array}$ & 65 & $14 \%$ \\
\hline 09 & $\begin{array}{l}\text { There is a formwork bulge; the formwork is } \\
\text { crooked }\end{array}$ & 144 & $30 \%$ \\
\hline 10 & Amendment method not meeting demands & 21 & $4 \%$ \\
\hline 11 & Concreting method and surface flat method & 16 & $3 \%$ \\
\hline 12 & $\begin{array}{l}\text { Due to workers' handicraft and careless } \\
\text { supervision }\end{array}$ & 9 & $2 \%$ \\
\hline Total & \begin{tabular}{l}
16 \\
\hline
\end{tabular} & $100 \%$ \\
\hline
\end{tabular}
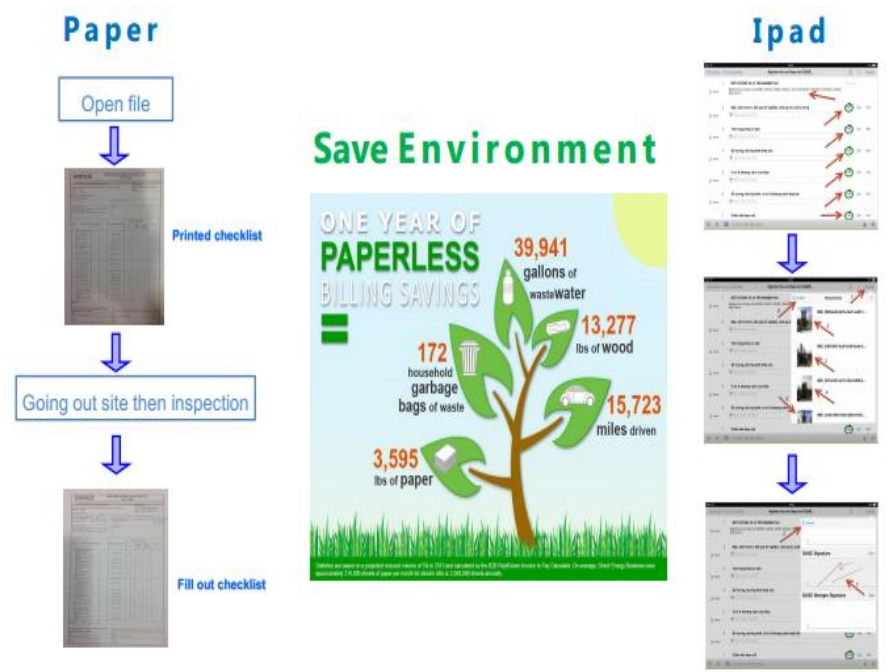

Fig. 2. Saving Papers by using iPad.
- Access to the project document at any time and any place, thanks to data storage on the cloud;

- Analyzing the core reasons leading to the poor construction quality works. From that basis, the project managers could propose solutions to remedy timely to avoid the repetition situation (e.g., the fault regarding the quality of the project exploiting, due to the formwork not being assured (30\%)). It is recommended that project managers place more focus on the execution of the work and the formwork acceptance process;

- To observe and to supervise the project from anywhere. Additionally, the project manager could access the project information that is updated daily through the system synchronization on the cloud.

- To observe the problems relating to the quality and remedy defects; to recognize the defective positions, so that there would be control over the remedy and the amendment.

- To have data as a basis for the evaluation of the subcontractor's capacity. In particular, at the time of executing the project, the defects caused by the subcontractor are found to account for $57 \%$. As a result, the project manager should pay more attention to the execution activities, inspection, and supervision of the subcontractor.

Despite the many benefits of the application of the BIM 360 Field in construction quality management, there are also some difficulties. Through the results of the BIM 360 Field applied in the actual projects, it was determined that employees apply the report submitted to managers as follows:

- Some employees do not get used to the new working style, so they still work slowly for about 01 month when performing a project.

- Continuously changing and instable human resources; as a result, this project needs time to retrain new employees. In particular, for the first 3 months of executing a project, the department of safety directed 2 employees to other projects.

- Department at the construction site allocated 3 employees to other projects. This also causes difficulties to the operation of the BIM 360 Field.

- The new project is only applied by the main contractor and the subcontractor, without extension for the owner and the consultancy company.

\section{CONCLUSION}

The BIM 360 Field is a modern approach which could improve the effectiveness of construction project quality management. This is a new method used to control project quality in Vietnam to replace the traditional acceptance method. However, the application of the BIM 360 Field also experiences some specific difficulties and challenges. As a result, great effort is really necessary to change the old mindset, so that the aim of the application of the BIM 360 Field could be reached. In reality, the research contributed a 
tool to contractors that supports effective construction quality assurance in a convenient and easy manner. Thanks to this technology application, the company could perform project quality management and update project progress anywhere and anytime. In this way, the management effectiveness could be improved, the cost would decrease, and the competitiveness could be increased. Regarding the theoretical basis, this research also aims to contribute to the guidelines to the BIM 360 application to perform construction project quality management.

\section{ACKNOWLEDGMENT}

The authors gratefully acknowledge Ho Chi Minh City Open University (HCMCOU), 97 Vo Van Tan Street, Ward 6, District 3, Ho Chi Minh City, 72407, Vietnam for their supporting this research.

\section{REFERENCES}

[1] P. T. Nguyen, T. A. Nguyen, Q. L. H. T. T. Nguyen, V. D. B. Huynh, and K. D. Vo, "Ranking project success criteria in power engineering companies using fuzzy decision-making method," International Journal of Advanced and Applied Sciences, vol. 5, no. 8, pp. 91-94, 2018.

[2] N. T. V. N. Phong, Nguyen; Luan Hong, Pham; Thu Anh, Nguyen; Quyen Le Hoang Thuy To, Nguyen; Vy Dang Bich, Huynh, "Application of supply chain management in construction industry," Advances in Science and Technology Research Journal, journal article vol. 12, no. 2, 2018.

[3] A. Khelifi and K. H. Hyari, "A Mobile Device Software to Improve Construction Sites Communications" MoSIC," International Journal of Advanced Computer Science and Applications, vol. 7, no. 11, pp. 51-58, 2016.

[4] N. T. Phong, V. Likhitruangsilp, and M. Onishi, "Developing a stochastic traffic volume prediction model for public-private partnership projects," in AIP Conference Proceedings, 2017, vol. 1903, no. 1, p. 060010: AIP Publishing.

[5] N. T. Phong and N. L. H. T. T. Quyen, "Application fuzzy multiattribute decision analysis method to prioritize project success criteria," AIP Conference Proceedings, vol. 1903, no. 1, p. 070011, 2017.

[6] N. L. H. T. T. Quyen, T. N. Phong, and D. B. H. Vy, "A hybrid multi criteria decision analysis for engineering project manager evaluation," International Journal of Advanced and Applied Sciences, vol. 4, no. 4, pp. 49-52, 2017.

[7] L. D. Nguyen, T. K. N. Nguyen, D. Q. Tran, and C. Villiers, "Productivity in Daytime and Nighttime Construction of Urban Sewer Systems," Journal of Construction Engineering and Management, vol. 140, no. 7, p. 04014021, 2014.

[8] Y.-H. Tsai, S.-H. Hsieh, and S.-C. Kang, "A BIM-enabled approach for construction inspection," in Computing in Civil and Building Engineering (2014), 2014, pp. 721-728.

[9] L.-C. Wang, "Enhancing construction quality inspection and management using RFID technology," Automation in Construction, vol. 17, no. 4, pp. 467-479, 2008.

[10] L. Chen and H. Luo, "A BIM-based construction quality management model and its applications," Automation in Construction, vol. 46, pp. 6473, 2014.

[11] F. Y. Y. Ling and T. T. D. Bui, "Factors affecting construction project outcomes: case study of Vietnam," Journal of Professional Issues in Engineering Education and Practice, vol. 136, no. 3, pp. 148-155, 2009.

[12] A. M. Gaber, S. Mazen, and E. E. Hassanein, "Comparative Study for Software Project Management Approaches and Change Management in the Project Monitoring \& Controlling," International Journal of Advanced Computer Science and Applications, vol. 7, pp. 259-264, 2016.

[13] M. Ashraf et al., "A Study on Usability Awareness in Local IT Industry," International journal of advanced computer science and applications, vol. 9, no. 5, pp. 427-432, 2018.
[14] J. Matthews, P. E. Love, S. Heinemann, R. Chandler, C. Rumsey, and O. Olatunj, "Real time progress management: Re-engineering processes for cloud-based BIM in construction," Automation in Construction, vol. 58, pp. 38-47, 2015.

[15] L. Nguyen, A. Koufakou, and C. Mitchell, "A smart mobile app for site inspection and documentation," in Proceedings of ICSC15-The Canadian Society for Civil Engineering 5th International/11th Construction Specialty Conference, University of British Columbia, Vancouver, Canada, 2015.

[16] A. A. Bubshait and T. H. Al-Atiq, "ISO 9000 quality standards in construction," Journal of Management in Engineering, vol. 15, no. 6, pp. 41-46, 1999.

[17] D. Arditi and H. M. Gunaydin, "Total quality management in the construction process," International Journal of Project Management, vol. 15, no. 4, pp. 235-243, 1997.

[18] L. Duy Nguyen, S. O. Ogunlana, and D. Thi Xuan Lan, "A study on project success factors in large construction projects in Vietnam," Engineering, Construction and Architectural Management, vol. 11, no. 6, pp. 404-413, 2004.

[19] Y. Luo, Cooperative Design, Visualization, and Engineering. Springer, 2007.

[20] T. A. Nguyen and P. T. Nguyen, "Explaining model for supervisor's behavior on safety action based on their perceptions," ARPN Journal of Engineering and Applied Sciences, Article vol. 10, no. 20, pp. $9562-$ 9572, 2015.

[21] P. T. Nguyen, P. Van Nguyen, Q. L. H. T. To Nguyen, and V. D. B. Huynh, "Project success evaluation using TOPSIS algorithm," Journal of Engineering and Applied Sciences, Article vol. 11, no. 8, pp. 1876-1879, 2016.

[22] Y. Chen and J. M. Kamara, "Using mobile computing for construction site information management," Engineering, construction and architectural management, vol. 15, no. 1, pp. 7-20, 2008.

[23] P. T. Nguyen, T. A. Nguyen, N. T. H. Ha, and T. N. Nguyen, "Facilities management in high rise buildings using building information modeling," (in English), International Journal of Advanced and Applied Sciences, Article vol. 4, no. 2, pp. 1-9, Feb 2017.

[24] M. El-Mekawy, A. Östman, and I. Hijazi, "An evaluation of IFCCityGML unidirectional conversion," International Journal of Advanced Computer Science and Applications, vol. 3, no. 5, pp. 159-171, 2012.

[25] S. Azhar, "Building information modeling (BIM): Trends, benefits, risks, and challenges for the AEC industry," Leadership and management in engineering, vol. 11, no. 3, pp. 241-252, 2011.

[26] D. Bryde, M. Broquetas, and J. M. Volm, "The project benefits of building information modelling (BIM)," International journal of project management, vol. 31, no. 7, pp. 971-980, 2013.

[27] B. McGuire, R. Atadero, C. Clevenger, and M. Ozbek, "Bridge information modeling for inspection and evaluation," Journal of Bridge Engineering, vol. 21, no. 4, p. 04015076, 2016.

[28] C. Eastman, P. Teicholz, R. Sacks, and K. Liston, BIM handbook: A guide to building information modeling for owners, managers, designers, engineers and contractors. John Wiley \& Sons, 2011.

[29] A. Sattineni and T. Schmidt, "Implementation of mobile devices on jobsites in the construction industry," Procedia Engineering, vol. 123, pp. 488-495, 2015.

[30] J. Wong, X. Wang, H. Li, and G. Chan, "A review of cloud-based BIM technology in the construction sector," Journal of information technology in construction, vol. 19, pp. 281-291, 2014.

[31] J. Wang et al., "Integrating BIM and LiDAR for real-time construction quality control," Journal of Intelligent \& Robotic Systems, vol. 79, no. 3-4, pp. 417-432, 2015.

[32] S. Cox, J. Perdomo, and W. Thabet, "Construction field data inspection using pocket PC technology," in International Council for Research and Innovation in Building and Construction, CIB w78 conference, 2002.

[33] T.-H. Chuang, B.-C. Lee, and I.-C. Wu, "Applying cloud computing technology to BIM visualization and manipulation," in 28th International Symposium on Automation and Robotics in Construction, 2011, vol. 201, no. 1, pp. 144-149. 
[34] M. S. Moran, "Assessing the benefits of a field data management tool," 2012.

[35] A. Sawhney and J. U. Maheswari, "Design coordination using cloudbased smart building element models," International Journal of Computer Information Systems and Industrial Management Applications, vol. 5, pp. 445-453, 2013.

[36] Y. Jiao, S. Zhang, Y. Li, Y. Wang, and B. Yang, "Towards cloud augmented reality for construction application by BIM and SNS integration," Automation in construction, vol. 33, pp. 37-47, 2013.
[37] R. Davies and C. Harty, "Implementing 'Site BIM': a case study of ICT innovation on a large hospital project," Automation in Construction, vol. 30, pp. 15-24, 2013.

[38] R. P. L. Fernandes, "Advantages and disadvantages of BIM platforms on construction site," 2013.

[39] J. Zhang, Q. Liu, F. Yu, Z. Hu, and W. Zhao, "A framework of cloudcomputing-based BIM service for building lifecycle," in Computing in Civil and Building Engineering (2014), 2014, pp. 1514-1521.

[40] B. E. Gleason, P. D. White, K. E. Kumpula, and J.-H. Woo, "The Use of Mobile Devices to Create Value in Quality Management Systems," in 50th ASC Annual International Conference Proceedings, 2014. 